\title{
Professional requirements for private practice in the Egyptian society, from the viewpoint of social work academics and practitioners who are working with family problems
}

\section{Asmaa M. El-Gafrawy}

Associate Professor at the Department of Social Work Fields

Faculty of Social Work, Helwan University

\section{Amal A. El-Gammal}

Associate Professor at the Department of Social Planning

Faculty of Social Work-Helwan University \& Qatar University 



\begin{tabular}{||lr|}
\hline The Egyptian Journal of Social Work (EJSW) & www.ejsw.org \\
ISSN: 2356-9204 & Vol 1, No.5, January 2018 \\
\hline
\end{tabular}

\title{
Professional requirements for private practice in the Egyptian society, from the viewpoint of social work academics and practitioners who are working with family problems
}

\author{
Asmaa M. El-Gafrawy (PhD) \\ Associate Professor at the Department of Social Work Fields \\ Faculty of Social Work, Helwan University \\ Amal A. El-Gammal (PhD) \\ Associate Professor at the Department of Social Planning \\ Faculty of Social Work-Helwan University \& Qatar University
}

\begin{abstract}
:
This study aimed to determine the professional requirements for the private practice of social work in Egypt, from the viewpoint of social work academics and practitioners who work with families, The study sample comprised all academics of Helwan University, and field practitioners. The sample size was 40 faculty members of the Faculty of Social Work at Helwan University, including a comprehensive survey of all social workers (37) working in the Family Consultancy Offices and Family Courts in the Helwan area .The main results showed the following: There are statistically significant differences between academics and practitioners in the perceived requirements of social service education needed to prepare a special practitioner to deal with family problems. There are statistically significant differences between academics and practitioners in the perceived requirements of field training needed to prepare a special practitioner to deal with family problems. There are statistically significant differences between academics and practitioners in the perceived requirements of the institutions of special practice needed to prepare the special practitioner to deal with family problems

Keywords: requirements of private practice of social work.

\section{Introduction:}

The private practice of social work in the United States and many European countries has grown exponentially. The proportion of social workers working in private practices was initially $9 \%$, growing to around $15 \%$ and then reaching about $25 \%$ of the total number of social workers in these countries. Thus, private practice has become an significant reality, and there is no disagreement over the importance of its existence and the greatness of its return (Abo elNasr. M: 2017, p. 76).
\end{abstract}




\section{The Egyptian Journal of Social Work (EJSW) www.eisw.org \\ ISSN: 2356-9204 Vol 1, No.5, January 2018}

Many research studies in the social work profession have shown that private practice is very attractive to social workers for the financial and moral gain, and social status that can be derived.

The results of the (Frisman, Linda study (2009,) highlighted the opportunities available to social workers when practicing privately, including: administrative flexibility; independence; working freely without constraints, dilemmas, boundaries and regulations of the governmental agencies; working more professionally than in institutional work; flexible working hours; ease of movement in the field, and ease of making family or household visits (p.18)

This study is based on the theory of general system. It is consistent with what it has defined, as the transformations required providing professional assistance to solve family problems, and add processes aimed at implementing special practice in Egypt. Study programs that contribute to the development of curricula incorporating special practice should include determining the appropriate time for the application of special practice after its re-enactment through laws legislation, community recognition and by intensifying the mass media. Coordinating with colleges and institutes of social service in the preparation of programs suitable for private practice at the level of masters and doctorate. Use of evaluation methods for the achievement of these programs of study in addition to private practice. According the study the outputs are: private practices and social services, and the feedback is: dealing with social issues to solve family problems.

The results of the Broenca Teresa \& Cristina Simone study (2013) confirmed that social workers are attracted to working in private agencies for several reasons, the most important of which was achieving professional independence. Ensuring professional stability and achieving financial profit were also important factors. The researchers also took the opinion of a sample of clients to determine why they preferred private agencies; the answer was that they found more confidentiality of their information, more responsibility and a higher level of professionalism through working in private agencies.

In their comparative study of public or governmental social agencies "that provide social support services to families" with private agencies operating in the same field, from the viewpoint of beneficiaries, Geens Naomi, Roots Griet and Vandenbroeck have found a preference from families for private agencies because they provide integrated social support. This support is presented through competent specialists using modern methods and strategies, including 


\section{The Egyptian Journal of Social Work (EJSW) www.eisw.org \\ ISSN: 2356-9204 Vol 1, No.5, January 2018}

intensive focus group discussions with families, acceptance, welcome and support, and the development of a sense of loyalty to the family. Whereas the study found that the social agencies of government were characterized by bureaucracy (Michelle, 2006). Lord .A. Susan \& John Indices (2015) studied a sample of NASW social workers working in private agencies to assess and evaluate their performance and commitment to the social work code of ethics. The study found that a better selection and a higher level of applications from social workers with private practice is due to achieving higher financial gains and being more focused on change in clients rather than in social systems National Association of Social Workers.

Private practitioners are subject to the system enforced by insurance companies that is able to regulate the services they provide to clients. This requires increased focus on remedial plans that contain behavioral change, a number of paid sessions, as well as other professional strategies see: (Greer and Rennie D, L. 2006; \& Thomas, S. P, 2010).

The private practice of social work has witnessed a global development, not coincidentally. Private practice in the USA began in 1958 when the National Association of Social Workers in New York declared that it would recognize the private practice of social workers as part of the social work profession

From 1983 to the beginning of the 1990s, most offices of private practice of social work were confined to marriage counselling and psychotherapy. After the 1990s, private practice offices began to engage in other areas such as research and training (Rosalie Ambrosine .et .al: 2005)

Egypt is the first country in which the education and practice of social work in the Arab world and the Middle East, and perhaps the third world, began. However, this concept and this form of private practice did not take into account the teaching and practice of social work in Egypt (Abdelmaguid. H: 2008, p. 3)

In Egypt, the beginnings of interest in private practice came in 1973, when the law of practicing social work, no.45 of 1973, was declared. In addition, in 1993, law no.104 was issued, which included comprehensive amendments, especially with regard to article no.8, which said that the practice of social work is only to be carried out by those holding social work qualifications, having graduated from faculties and institutes of social work. Now a new law proposal, prepared by the Social Work Union, includes an article (no. 4) 


\section{The Egyptian Journal of Social Work (EJSW) www.ejsw.org \\ ISSN: 2356-9204 Vol 1, No.5, January 2018}

stipulating the scientific and professional level of those authorized to open an office, private office or center for consultation (Al-Hamid Thuraya 2000)

Nevertheless, interest in the social work profession in Egypt, especially in the area of private practice, is still weak or limited, which has meant that clear evidence of private practice social work in Egypt is lacking.

Several research studies confirm the existence of many obstacles that impede the application of private practice in Arab society in general and in Egyptian society in particular. The study of Farouk E. Mohamed, (2013) indicates some obstacles that limit the spread of private practice in Omani society. Some of these obstacles are related to social workers, the profession, academic institutions, societal awareness and acceptance, legislations, laws and monitoring, and financial considerations .

Suggestions for dealing with these obstacles are offered in the same study. The study also stressed the need for Omani society to adopt private practice social work, and the need to qualify social workers for work in offices or centers of private practice, especially in the field of family, social and psychological counselling.

According to the results of the Abdallah. H. Awad study, (2012) there are many variables associated with the issue of private practice in Egypt. The most important social variables are: solving the unemployment problem of graduates of social work. The most important economic variables are: population growth, low per capita income, and privatization. The political variables, especially after the revolution of 25 January, are: freedom of opinion. The professional variables include the importance of field training, and the modification of the educational curriculum in social work .

The study of Hussein, Eman Jaber, (2009) aimed to determine the requirements of professional practice in the social work profession in the field of family care, and to determine the professional controls and requirements required by the private practice offices, as well as to identify the most significant difficulties that may face the implementation of private practice in the field of family care. The study concluded that there is a great need for a number of professional controls and requirements to implement private practice in the family care field, including the following requirements (ethical, legal, administrative, technical and media) . 


\begin{tabular}{||lr||}
\hline The Egyptian Journal of Social Work (EJSW) & www.ejsw.org \\
ISSN: $2356-9204$ & Vol 1, No.5, January 2018 \\
\hline
\end{tabular}

In the Jurkowsk Elaine study, (2015) some of the requirements for the success of private practice were identified as: licenses, attention to education, continuing training, and social workers' success in social work examinations.

When comparing the private practice of social work in the USA to the situation in Egypt, we can see that there are many difficulties that limit the implementation of private practice in Egypt. The most important are: the weakness of social work education and field training, and its inability to keep up with global developments and standards, the weakness of efficiency of the majority of social service agencies, the weakness of professional organizations of social work (Abdul Maguid.H: 2008)

Shedler, J (2010) identified a number of difficulties faced by private practice, concluding that it needs time and effort, and perhaps to formulate a clear policy

Based on the results of these previous research studies, whether foreign or Arab, the current study problem is formed as following: Determining the professional requirements for the private practice of social work in Egypt, from the viewpoint of social work academics and practitioners who work with families

\section{Goals:-}

The main goal of the current study is to determine the professional requirements for the private practice of social work in Egypt, from the viewpoint of social work academics and practitioners who work with families. Supported by achieving the following subaims: define the requirements of social work education, determine the requirements of field rehabilitation, and determine the requirements of the professional practice agencies

\section{Hypotheses:}

The main hypothesis of the study is: There are statistically significant differences between the professional requirements and the application of private practice social work in Egypt, from the viewpoint of social work academics and practitioners who work with families

A number of sub-hypotheses emerge from the main hypothesis as follows:

There are statistically significant differences between social work education and the application of private practice social work in Egypt, from the viewpoint of social work academics and practitioners who work with families. 


\section{The Egyptian Journal of Social Work (EJSW) www.eisw.org \\ ISSN: 2356-9204 Vol 1, No.5, January 2018}

There are statistically significant differences between field rehabilitation and the application of private practice social work in Egypt, from the viewpoint of social work academics and practitioners who work with families

There are statistically significant differences between institutions of professional practice and the application of private practice social work in Egypt, from the viewpoint of social work academics and practitioners who work with families

\section{Concepts:}

The concept of requirements Private Practice

NASW (2013) argues that private practice is best practiced by licensed clinical social workers, whether individually or collectively, to provide services such as assistance with social relationships, and mental health problems. The social worker receives customer fees directly or from third parties such as insurance companies.

In light of the above, the present study considers that the special practice of social service is :"A professional and social treatment process, which is provided by two independent professional specialists, for a material wage, through appropriate vocational training in social service education. These services are supervised by state regulators" to and to determine the needs of education, field rehabilitation, the professional practice agencies that can be scaled by questionnaires.

\section{Methodology:}

The study is of the descriptive type, based on the social survey method, applied to a sample of private practice social workers in Egypt, from the viewpoint of academics and practitioners in the social work profession

Population: Random sample (40) faculty members and assistants from different scientific departments of the Faculty of Social Work at Helwan University were selected in the academic year 2016-2017.

A comprehensive survey of all social workers working in the Family Consultancy Offices and Family Courts in the Helwan area. The total number of these social workers was (37 practitioners)

The study was implemented in the Faculty of Social Work, Helwan University, Ain Helwan, Cairo Governorate and in all the Family Consultancy Offices and Family Courts in the Helwan area The dates the study ran were $14 / 03 / 2017$ to $24 / 05 / 2017$. 


\section{The Egyptian Journal of Social Work (EJSW) www.eisw.org \\ ISSN: 2356-9204 \\ Vol 1, No.5, January 2018}

\section{Study Tool:}

The study is of the descriptive type, based on the social questionnaire method, applied to a comprehensive survey of private practice social work in Family Consultancy Offices, from the viewpoint of random sample of academics and practitioners in the social work profession. There are three dimensions of questionnaire. First dimension has 12 items, the second one has 15 items, third has 10 items. the respond to questionnaire were Strongly Agree $=5$, Agree $=4, \quad$ Neutral $=3$, Strongly Disagree $=2$, Disagree $=1$

Table. No. (1) Reliability of results using the Pearson correction coefficient $(\mathrm{N}=10)$

\begin{tabular}{||c||c||}
\hline \multicolumn{1}{|c||}{ Variable } & $\begin{array}{c}\text { Pearson correlation } \\
\text { coefficient }\end{array}$ \\
\hline \hline $\begin{array}{l}\text { Questionnaire for the professional requirements for } \\
\text { the private practice of social work in the field of } \\
\text { family issues in Egypt }\end{array}$ & 0.89 \\
\hline
\end{tabular}

Table no. (1) shows that there is a strong correlation between the first application and the re-application of the questionnaire, which means that the questionnaire can be relied on to a high degree, whilst drawing on the results that can be obtained from it. Also, the reliability of the questionnaire was calculated using the Alpha Kronbach coefficient. The results were as follows:

Table no. (2) Reliability of results using the Alpha Kronbach coefficient $(\mathrm{N}=15)$

\begin{tabular}{||c||c||}
\hline Variable & $\begin{array}{c}\text { Alpha Kronbach } \\
\text { coefficient }\end{array}$ \\
\hline $\begin{array}{l}\text { Questionnaire for the professional requirements for the private } \\
\text { practice of social work in the field of family issues in Egypt }\end{array}$ & 0.91 \\
\hline \hline
\end{tabular}

These levels of the Pearson correction coefficient (0.89) and the Alpha Kronbach coefficient (0.91) are high, acceptable and dependable in their findings, enabling the researcher to arrive at more honest and objective results from the study questionnaire.

Fifth: Statistical treatments and tests: The statistical analysis program SPSS Version 20 was used to tabulate the research. Also, the following statistical treatments and tests were used:

The Pearson correction coefficient; the Alpha Kronbach coefficient; Frequency and percentage; The arithmetic mean and the standard deviation; Weighted weights and estimated percentage; The alpha coefficient. 


\section{\begin{tabular}{|l|r|}
\hline The Egyptian Journal of Social Work (EJSW) & www.eisw.org \\
ISSN: 2356-9204 & Vol 1, No.5, January 2018 \\
\hline
\end{tabular}}

\section{Results:}

Table no. (3) Description of the respondents:

\begin{tabular}{|c|c|c|c|c|c|}
\hline \multirow{2}{*}{ No } & \multirow{2}{*}{ Sex } & \multicolumn{2}{|c|}{ "academics } & \multicolumn{2}{|c|}{ Practitioners } \\
\hline & & $\%$ & $\bar{F}$ & 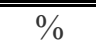 & $\bar{F}$ \\
\hline 1 & Male & 37.5 & 15 & 43.2 & 16 \\
\hline \multirow[t]{2}{*}{2} & Female & 62.5 & 25 & $\bar{~} 56.8$ & 21 \\
\hline & Total & $100 \%$ & 40 & $100 \%$ & 37 \\
\hline No. & Age & $\%$ & $\overline{F F}$ & $\%$ & $\overline{F F}$ \\
\hline 1 & Less than 30 years & 10 & 4 & 8.1 & 3 \\
\hline 2 & $30-$ & 27.5 & 11 & 24.32 & 9 \\
\hline 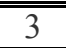 & 40- & $\overline{52.5}$ & 21 & 35.13 & 12 \\
\hline \multirow[t]{2}{*}{ 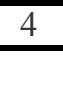 } & 50 years and more & 10 & 4 & 35.13 & 13 \\
\hline & Total & $100 \%$ & 40 & $100 \%$ & 37 \\
\hline No. & "educational status & $\%$ & $\bar{F}$ & $\%$ & F F \\
\hline 1 & Hold a qualification less than bachelor degree & 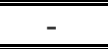 & 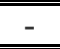 & 43.24 & 16 \\
\hline 2 & Hold a bachelor degree in social work & 25 & 10 & 56.75 & 21 \\
\hline 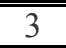 & "Hold a master degree in social work & 30 & 12 & - & - \\
\hline 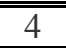 & Hold a PhD in social work & 45 & 18 & 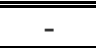 & 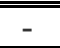 \\
\hline 5 & $\begin{array}{c}\text { Total } \\
\end{array}$ & $100 \%$ & 40 & $100 \%$ & 37 \\
\hline No. & Occupation & $\%$ & $\overline{\mathrm{F}}$ & $\%$ & $\overline{\mathrm{F}}$ \\
\hline 1 & $\begin{array}{c}\text { Social worker } \\
\end{array}$ & 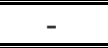 & - & 94.60 & 35 \\
\hline 2 & Researcher in social work & 7.5 & 3 & 5.40 & 2 \\
\hline 3 & "Demonstrator in social work & 7.5 & 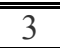 & - & - \\
\hline 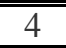 & בAssistant teacher in social wok & 17.5 & 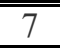 & 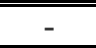 & 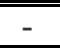 \\
\hline 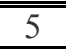 & Teacher in social work & 35 & 14 & 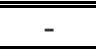 & 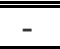 \\
\hline 6 & Associate Professor in Social Work & 30 & 12 & - & - \\
\hline 7 & Professor in Social Work & 2.5 & 1 & - & - \\
\hline & Total & $100 \%$ & 40 & $100 \%$ & 37 \\
\hline
\end{tabular}

Table no. (3) Shows that females who took part in the sample represented the largest group. The percentage of female academics reached $62.5 \%$, and the percentage of female practitioners reached $56.8 \%$. This may be due to women's interest in the social work profession and issues affecting families.

The table shows that the distribution of respondents by age was the highest for academics in the 40-50 years age group, up to $52.5 \%$. Moreover, the largest group in the research sample as a whole is aged between 40 and 50 years $(42.9 \%)$, indicating the maturity and experience of the respondents in the current study.

The table shows the distribution of respondents according to their educational status. Academics with a doctorate represent the largest group among academics (45\%), while the largest group among 


\section{The Egyptian Journal of Social Work (EJSW) www.eisw.org \\ ISSN: 2356-9204 \\ Vol 1, No.5, January 2018}

practitioners have a bachelor's degree in social work (56.75\%). Which also indicates that the respondents in the study are specialists and practitioners in the profession of social work.

The table shows the distribution of respondents according to occupation. Teachers of social work, at the Faculty of Social Work Helwan University, represented the largest proportion of academics at $35 \%$, followed by the associate professors in social work at $30 \%$. This means that about $65 \%$ of the academic sample are teachers and assistant professors in social work. The majority of respondents from the practitioners $(94.6 \%)$ are social workers.

Table. no. (4) Distribution of respondents obtaining training courses on family issues

\begin{tabular}{|l||l|l|l|l|l||}
\hline \multirow{2}{*}{ No. } & \multirow{2}{*}{ obtaining training courses on family issues } & \multicolumn{3}{|l|}{ Practitioners } & \multicolumn{2}{|c|}{ Academics } \\
\cline { 3 - 6 } & & $\mathbf{\%}$ & $\mathrm{F}$ & $\mathbf{\%}$ & $\mathrm{F}$ \\
\hline \hline 1 & Yes & $\mathbf{8 3 . 8}$ & $\mathbf{3 1}$ & $\mathbf{3 5}$ & 14 \\
\hline $\mathbf{2}$ & No & $\mathbf{1 6 . 2}$ & $\mathbf{6}$ & $\mathbf{6 5}$ & 26 \\
\hline \hline & Total & $\mathbf{1 0 0} \%$ & $\mathbf{3 7}$ & $\mathbf{1 0 0} \%$ & 40 \\
\hline
\end{tabular}

Table no. (4) Shows the distribution of respondents according to obtaining training courses on family issues. Practitioners scored the highest percentage with $(83.8 \%$ ) obtaining courses, while only $35 \%$ of respondents in the academic sample obtained such courses.

Second: The requirements of the professional practice to confront family problems.

Table no. (5) Subjects of training courses obtained

\begin{tabular}{|l||l||l|l||l|}
\hline \multirow{2}{*}{ Subjects of training courses obtained } & \multicolumn{2}{l|}{ Practitioners } & \multicolumn{2}{l|}{ Academics } \\
\cline { 2 - 6 } & $\mathbf{\%}$ & $\mathbf{F}$ & $\mathbf{\%}$ & F \\
\hline Resolving family disputes & 34.37 & 22 & 40 & 10 \\
\hline Marital problem-solving skills & 34.37 & 22 & 16 & 4 \\
\hline Professional intervention strategies to solve problems & 25 & 16 & 24 & 6 \\
\hline \hline Skills of dialogue and persuasion & 6.26 & 4 & 20 & 5 \\
\hline \hline Total & $100 \%$ & 64 & $100 \%$ & 25 \\
\hline
\end{tabular}

Table no. (5) Shows the distribution of the subjects of the training courses obtained. The academics received four training courses, ranked in order as following: resolving family disputes $(40 \%)$ followed by the professional intervention strategies to solve problems $(24 \%)$ then skills of dialogue and persuasion (20\%) and finally marital problem solving skills (16\%) Also, practitioners received four training courses, ranked in order as following: resolving family disputes (34.7\%), marital problems solving (34.7\%), professional intervention strategies to solve problems $(25 \%)$, then skills of dialogue and persuasion came in last place with $6.2 \%$. 
The Egyptian Journal of Social Work (EJSW) www.ejsw.org

ISSN: 2356-9204

Vol 1, No.5, January 2018

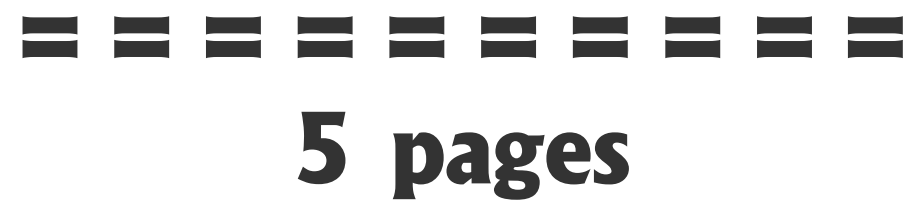




\section{The Egyptian Journal of Social Work (EJSW) www.ejsw.org \\ ISSN: 2356-9204 \\ Vol 1, No.5, January 2018}

Table no. (8) shows the requirements of teaching social work in order to prepare the generalist practitioner to solve family problems, as reflected by the responses of academics. Ranked according to importance they are as follows: The first requirement was "suit the courses of study with the requirements of the labor market". The last requirement was "understanding social statistics science to conduct social research on families". The requirements for teaching social work in order to prepare the private practitioner to solve the family problems, as stated in the responses of the practitioners, are ranked according to importance as follows: The first requirement was to take care of postgraduate studies and develop private practice courses, the last requirement was "Amend educational regulations and laws to incorporate private practices".

Table. no. (9) Differences between respondents (academics and practitioners) and the professional requirements of the private practice of social work with families in Egypt

\begin{tabular}{|c|c|c|c|c|c|}
\hline No & the professional requirements & $\begin{array}{l}\text { T. test } \\
\text { value }\end{array}$ & $\begin{array}{l}\text { Standard } \\
\text { deviation }\end{array}$ & $\begin{array}{l}\text { The weighted } \\
\text { average }\end{array}$ & $\mathrm{N}$ \\
\hline \multirow[t]{2}{*}{1} & \multirow[t]{2}{*}{ Social work education } & \multirow{2}{*}{$\begin{array}{c}- \\
3.916 * *\end{array}$} & 0.121 & 4.2 & 40 \\
\hline & & & 0.185 & 3.97 & 37 \\
\hline \multirow[t]{2}{*}{2} & \multirow[t]{2}{*}{ Field training } & \multirow[t]{2}{*}{$4.109 * *$} & 0.191 & 4.36 & 40 \\
\hline & & & 0.112 & 4.10 & 37 \\
\hline \multirow[t]{2}{*}{3} & \multirow{2}{*}{$\begin{array}{l}\text { the institutions of } \\
\text { professional private practice }\end{array}$} & \multirow[t]{2}{*}{$9.504 * *$} & 0.115 & 4.42 & 40 \\
\hline & & & 0.109 & 4.04 & 37 \\
\hline \multirow[t]{2}{*}{4} & \multirow{2}{*}{$\begin{array}{l}\text { professional private practice } \\
\text { to face family problems }\end{array}$} & \multirow{2}{*}{$3.834 * *$} & 0.11 & 4.32 & 40 \\
\hline & & & 0.06 & 4.03 & 37 \\
\hline
\end{tabular}

Significant at 0.01 df. $=$ degree of freedom ${ }^{*}$ Significant at 0.05

Table.no. (9) shows: 1-There are significant differences between the academics and the practitioners on the requirements of social work education to prepare the generalist practitioner to solve the family problems, where the value of T-test $=-3.916^{* *}$. It is a significant at the (0.01) level 2-There are significant differences between the academics and practitioners on the requirements of field training for the preparation of the generalist practitioner to solve family problems, where the value of T-test $=4.109 * *$. It is a significant at the (0.01) level

.3-There are significant differences between the academics and practitioners on the requirements of institutions of private practice to prepare the generalist practitioner to solve family problems ، where the value of T-test $=9.504 * *$ is a significant at the $(0.01)$ level. 


\begin{tabular}{||lr||}
\hline The Egyptian Journal of Social Work (EJSW) & Www.ejsw.org \\
ISSN: $2356-9204$ & Vol 1, No.5, January 2018 \\
\hline
\end{tabular}

4- There are significant differences between the academics and practitioners on the professional private practice to face family problems, where the value of T-test $3.834 * *$ is a significant at the (0.01) level

\section{Discussion:}

The current study indicates that the requirements of teaching social work to prepare private practitioners is (high), since the mean= 4.42. This means that the study population recognizes the importance of the requirements in teaching social work and the need to "suit courses of study with the requirements of the labor market". The results of the study indicate that the need to "Understand recent trends in the practice of social work to deal with family problems" is an important requirement of teaching, and records (average), since the mean $=4.37$.

Furthermore, the present study indicates that the level of field training requirements for private practitioners to cope with family problems is (high), since the mean $=2.56$, and this shows that most of the subjects indicate that they want training on the role of social workers in private institutions and offices. The study data indicates that respondents want training on the application of the principles of social work when working with families in institutions of private practice, which agrees with Greer and Rennie (2010 (

The results of the study emphasize the importance of the requirement of teaching social work in the family field, in order to prepare a private practitioner in the field of family problems, this must be achieved in a scientific manner that applies professional ethics and strategy to intervene professionally in family cases. This requires field training for social service students in the family field for at least 400 hours, including preparation and weight of skills in order to be able to deal professionally in the offices of private practice for families. This is confirmed by literature and studies such as (Broenca Teresa \& Cristina Simone (2013), Lord A. Susan \& John Indices 2012) (

The results of the study are carefully separated from each of the requirements of special practice in the family domain as follows, according to the views of social service academics and practitioners in the family field:

The field training requirements for the private practitioner to address family problems, in order of importance from the perspective of practitioners, are as follows: The first requirement was training on the professional methods used, the second requirement was not less 


\section{The Egyptian Journal of Social Work (EJSW) www.ejsw.org \\ ISSN: 2356-9204 Vol 1, No.5, January 2018}

than 400 hours of training in family offices, the last requirement was training to study the category of clients who most benefit from the services of the private social institutions. The results are in line with the study of Greer and Rennie (2010) and the study of Thomas (2010), who emphasized the need for increasing field training with attention to treatment plans that contain a number of paid sessions as well as other professional strategies .

The requirements that must be met in the institutions of professional private practice to deal with family problems, from the viewpoint of academics, ranked in order of importance, are as follows: The first requirement was to provide continuous training courses for the teams of private practice institutions that deal with family problems, the second was the requirement to develop a code of ethics for the practice of social work in the face of family problems, the last requirement was the establishment of a body to organize and issue licenses for the offices of private practice.

The results show the requirements that must be met in the institutions of professional private practice to deal with family problems, from the viewpoint of practitioners. They are ranked in order of importance as follows: The first requirement was the allocation of a legal and administrative entity to guarantee the rights of both clients and private practitioners, the first requirement was developing a code of ethics for the practice of social work with families.

The requirements of teaching social work in order to prepare generalist practitioners to solve family problems, as reflected by the responses of academics, are ranked according to importance as follows: The first requirement was to "suit the courses of study with the requirements of the labor market". The last requirement was "Understanding social statistics science to conduct social research on families". The requirements for teaching social work to prepare private practitioners to solve family problems, as stated in the responses of the practitioners, are ranked according to importance as follows: The first requirement was to maintain the quality of postgraduate studies and develop private practice courses. The last requirement was "Amend educational regulations and laws to incorporate private practices" (Abdelmaguid. H, (2008), Abdellah, M. Awad, (2012), Baalbaki, M (2007) 


\begin{tabular}{||lr||}
\hline The Egyptian Journal of Social Work (EJSW) & Www.ejsw.org \\
ISSN: $2356-9204$ & Vol 1, No.5, January 2018 \\
\hline
\end{tabular}

Recommendation: Finally, the most critical requirements of success private practice in Egypt and may be Arab region must be: 1) the need to formulate professional laws and regulations for the establishment of special practice offices.2) Develop a moral charter for the private practitioner and strict penalties in the case of the violator. 3) Recognize the role of the media in raising awareness of the emergence of private practice offices. 4) The need for the private practitioner to receive continuous training in dealing with family problems. 5) Increase the availability of material and human resources to ensure that the offices of private practice can work effectively with families. 6) In addition, the need for follow-up and evaluation of the offices of special practice by the Ministry of Social Solidarity.

\section{References}

Abo-Nasr M.t (2017), Special practice and professional licenses in social service, Dar al-Kwet and Arabic Studies, p. 60.

Abdelmaguid. H (2008), Special Practice of Social Service between Global Application and Local Targeting, 18th Scientific Conference, Faculty of Social Work, Fayoum University.

Abdellah, M. Awad, (2012), The variables associated with moving the issue of the special practice of social service in society, Cairo, unpublished doctoral thesis, Faculty of Social Work, Helwan University.

Al-Hamid Thuraya (2000), Labneh, Union of Societies in the 21st Century, 13th Scientific Conference of the Faculty of Social Work, Helwan University, Cairo.

Baalbaki,M (2007), Dictionary of the resource, Beirut, Dar Alamal for millions, $\mathrm{p}$

Genes Naomi, Rotes Greet 2015 \& Vanden broeck Michel, Informal social support in contexts of diversity: shaping the relationship between the public and the private sphere, Health and Social Care in the Community 23 (5), 532-540 doi: 10.1111/hsc.12161, Ghent University, Ghent, Belgium.

Broenca Teresa \& Cristina Simone (2013), Motivation in paid work for non-profit organizations: the case of Private Social Solidarity Institutions, University of Porto, ISSN: 0870-8541.

EI Sanhoury Abdel Monem K (2009), Clinical Individual Service, Contemporary Theories and Trends Alexandria, The Modern University Office. 


\begin{tabular}{|l|r|}
\hline The Egyptian Journal of Social Work (EJSW) & www.eisw.org \\
ISSN: 2356-9204 & Vol 1, No.5, January 2018 \\
\hline
\end{tabular}

Elaine Murkowski (2015), social work licenses: implication for strength thinning social work practice in Egypt, Egyptian Journal of Social Work, Faculty of Social Work, Helwan University.

Farouk E . Mohamed (2013), Research published Journal of Studies in Social Work and Human Sciences, Faculty of Social Work, Helwan University, Issue 35, Cairo, October.

Frisman Linda (2009), social workers and private practice opportunities, administration and policy in mental health journal,vol,18.

Greer, L., \& Rennie, D. L. (2006), Providers and ayes' endorsement of empirically supported therapy: A power-knowledge relationship? Psychotherapy Research, 16(1), 67-79

Hussein Eman Jaber (2009), Requirements for Professional Practice for Social Work in the Family Sector, unpublished Master Thesis, Fayoum University, Faculty of Social Work.

James, D. (2003), from evidence-based practice to practice-based evidence: The idea of situated generalization. Research Papers in Education, 18(4), 347-364.

Lord .A.Susan \& John Indices (2012), Social Workers in Private Practice: A Descriptive Study of What they do, Published online:15 January 2011 _ Springer Science Business Media.P81.

National Association of Social Worker Standards for social service Manpower, Washington.D.C.NASW'2013.

National Association of Social Workers (2008), Code of Ethics of the National Association of Social Workers. Washington.

Rosalie Ambrosine .et .al (2005). Social Work: social welfare Australia: Brook/Cole, 4th. Ed

Thomas, S. P. (2010). The evidence for an "older"' therapy. Issues in Mental Health Nursing, 31, 305

Shedler, J. (2010). The efficacy of psychodynamic psychotherapy Simons, H., Kushner, S., Jones, K., \&American Psychologist, 65(2), 98-109. 